\title{
The use of hydroelectric lakes by giant otters Pteronura brasiliensis: Balbina lake in central Amazonia, Brazil
}

\author{
Fernando C.W. Rosas, Gália Ely de Mattos and Márcia Munick Mendes Cabral
}

\begin{abstract}
Data on the occurrence and habitat use of giant otters Pteronura brasiliensis in the $4,437 \mathrm{~km}^{2}$ of Balbina hydroelectric lake in central Amazonia, Brazil, were collected from September 2001 to December 2005. Twenty-nine groups of giant otters were recorded in an area corresponding to $10 \%$ of the total reservoir. Despite the fact that it is a hydroelectric lake, the water level can vary annually by up to $3.5 \mathrm{~m}$ with the Amazonian seasonal flood pulse. A total of 210 dens, communal latrines and campsites of giant otters were located. An average of $37 \%$ of the dens observed were classified as in use, and the species was recorded in the lake throughout the year. Giant otters started their daily activities between 05.23 and 08.05. The average height of den
\end{abstract}

openings was $28.77 \pm$ SD $10.00 \mathrm{~cm}$, with an average width of $56.11 \pm$ SD $19.17 \mathrm{~cm}$. Births in Balbina occur mainly during the period of high and receding water level, as reported for giant otters in other Amazonian areas. There are at least two conditions that enable the species to inhabit hydroelectric reservoirs: (1) presence of the species in the area before dam construction and (2) absence or low numbers of human communities around the reservoir. The potential use of hydroelectric lakes for the conservation of the giant otter in the Amazon is discussed.

Keywords Amazonia, Balbina hydroelectric lake, Brazil, giant otter, habitat use, Pteronura brasiliensis.

\section{Introduction}

The giant otter Pteronura brasiliensis is a semi-aquatic mammal historically distributed from Guyana, across Venezuela and Colombia, and south to northern Argentina and west of the Andes (Carter \& Rosas, 1997). The species is gregarious and territorial, forming family groups of 2-16 individuals that guard and defend their territories, which are regularly marked using faeces and urine in several communal latrines within the family's range (Duplaix, 1980; Carter \& Rosas, 1997).

Giant otters are categorized as Threatened on the IUCN Red List (IUCN, 2006), with some southern populations extinct or Critically Endangered (Carter \& Rosas, 1997). The main factor responsible for the species' decline is that, until the middle of the last century, it was hunted for its pelt (Best, 1984; Carter \& Rosas, 1997; Rosas, 2004). Giant otters are no longer killed for this purpose and the species is protected by national laws in the majority of the countries where it occurs (Carter \& Rosas, 1997). However, habitat destruction, mining activities, oil and natural gas exploration, industrial

Fernando C.W. Rosas (Corresponding author), Gália Ely de Mattos and Márcia Munick Mendes Cabral Instituto Nacional de Pesquisas da Amazônia, Laboratório de Mamíferos Aquáticos, Caixa Postal 478, Manaus - AM, 69011 970, Brazil.

Received 22 May 2006. Revision requested 20 September 2006 Accepted 9 October 2006. pollution, and the theft of cubs to be sold as pets constitute additional threats to giant otters (Rosas, 2004). Although hydroelectric dams are probably geographical barriers for Amazonian aquatic mammals such as dolphins and manatees, isolating populations genetically (Rosas et al., 1991), this does not seem to be the case for giant otters.

Studies of habitat use by the giant otter are scarce and limited to a few specific places (Duplaix, 1980; Laidler, 1984; Schweizer, 1992; Schenck, 1999). In 2001 we obtained reports that giant otter groups had been observed in Balbina hydroelectric lake (S.M. Lazzarini, pers. comm.). The giant otters' ability to inhabit such lakes was previously unknown and the characteristics of these habitats used by the species in Brazil had not been studied. Here we examine the occurrence and use of Balbina lake by giant otters and discuss the conditions that appear to allow the species to use such habitats, as well as the potential use of these reservoirs for the conservation of the giant otter in the Amazon.

\section{Study area}

The data were obtained from systematic observations of resident groups of giant otters in the reservoir of Balbina Hydroelectric Power Plant (Fig. 1). This dam was built on the Uatumã River, a tributary of the north-west Amazon, and is $150 \mathrm{~km}$ from the city of Manaus, the capital of Amazonas state, in Central Amazonia, Brazil. 


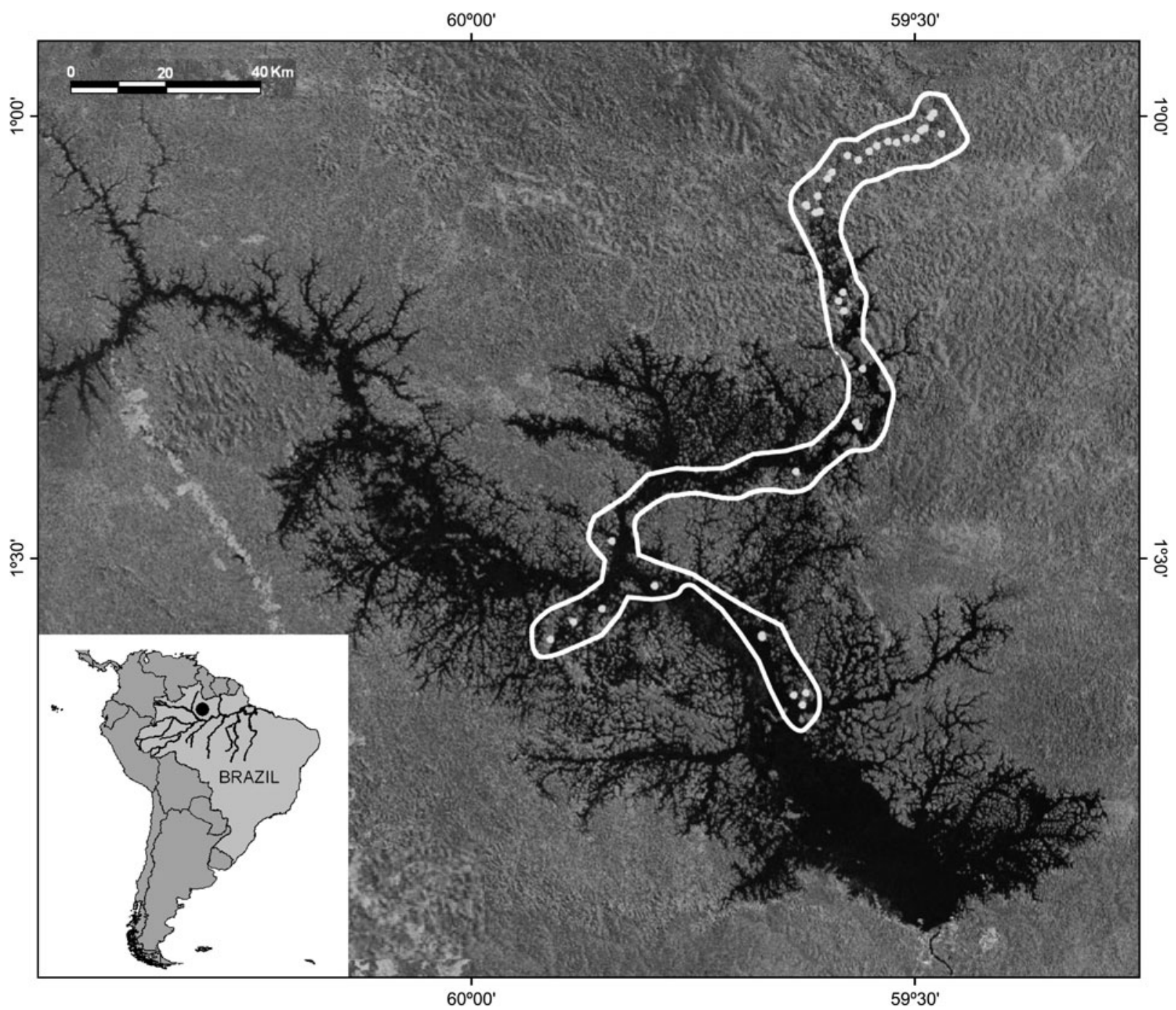

Fig. 1 Satellite image of Balbina lake. Dots represent giant otter dens classified as 'in use' at least $40 \%$ of the times they were visited between September 2001 and December 2005. The area surveyed is delimited by the white line. The black dot on the inset indicates the approximate location of Balbina lake in Brazil.

The Balbina sluice bases were closed in October 1987, and the lake took c. 16 months to fill until reaching the $50.6 \mathrm{~m}$ spillway level. The higher areas of land resulted in the formation of c. 3,300 islands. Current data obtained by the National Institute of Spatial Research (INPE) based on satellite images indicate an estimated flooded area of $4,438 \mathrm{~km}^{2}$ at the $51 \mathrm{~m}$ spillway level (FUNCATE/INPE/ANEEL, 2000), representing an area $88 \%$ greater than the value quoted by the electricity agency of northern Brazil (ELETRONORTE, 2005). Despite being a hydroelectric lake, the water level variation in the reservoir, which is measured daily at the hydro plant wall, follows a similar pattern to that of the rivers in central Amazonia, although on a smaller scale, enabling the definition of four hydroclimatic seasons: low water level (December-February), rising water level
(March-May), high water level (June-August) and receding water level (September-November; Sioli, 1984).

\section{Methods}

The data were collected between September 2001 and December 2005 using an $8 \mathrm{~m}$ boat with a $40 \mathrm{HP}$ outboard engine. In total we examined c. $10 \%\left(450 \mathrm{~km}^{2}\right)$ of the total area of the reservoir. In the first year we made monthly excursions, searching several areas of the lake thoroughly. However, because of logistical problems (fuel limitations and navigation difficulties within areas of dead trees), excursions were carried out every other month from the second year onwards. During these latter trips the previously marked dens were visited 


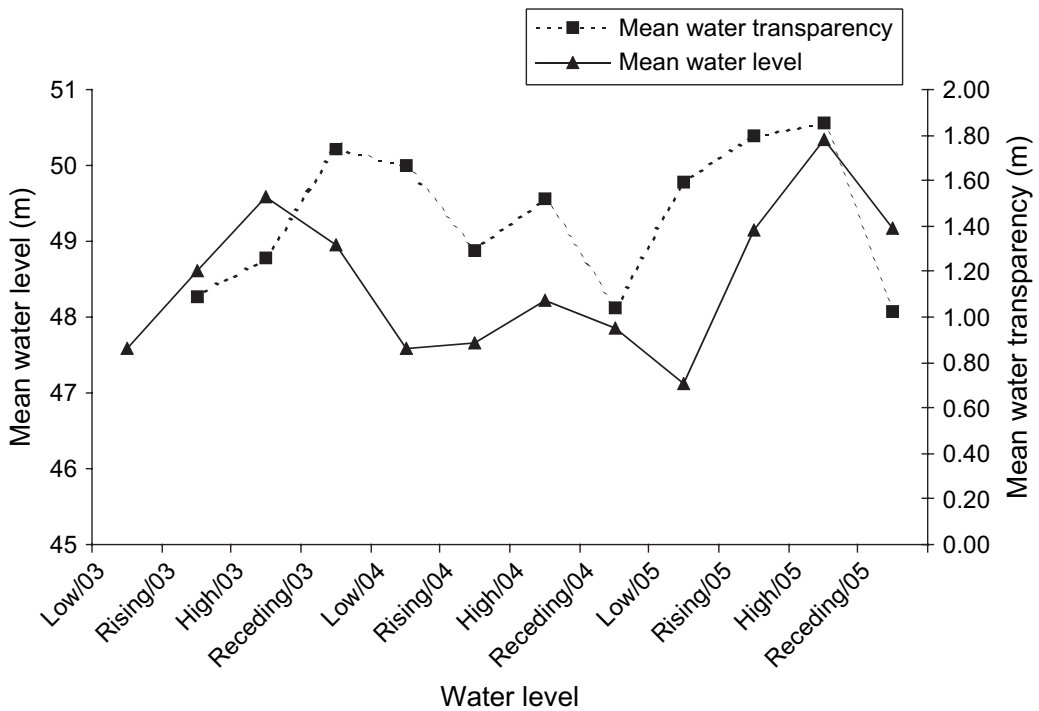

Fig. 2 Mean water level $(\mathrm{m})$ and mean water transparency $(\mathrm{m})$ of Balbina lake during 2003 and 2005 systematically. To record behaviour patterns and group dynamics we studied the upper portion of the lake, in the area of the Pitinga River, where navigation is easier and where some giant otter groups became habituated to our presence. We recorded the location of dens with a global positioning system (to an accuracy of $\pm 12 \mathrm{~m}$ ) and classified them as 'in use' and 'not in use', taking into consideration soil humidity in the surrounding area, occurrence of trampled vegetation, footprints, fresh faeces in nearby communal latrines, and/or presence of the animals in front of the den (Groenendijk et al., 2005). Animals were recognized using their individual neck marks. More than one animal seen together was characterized as a group. Groups were distinguished by using the individual neck marks and by location. Some dens classified as in use were monitored before dawn, and again at dusk, to determine the time giant otters leave and return. The dimensions of the entrances of some dens classified as in use were measured and their shapes recorded. Water transparency was recorded using a Secchi disk in front of several randomly chosen dens.

\section{Results}

One hundred and thirty individual giant otters were identified in Balbina lake, in 29 groups. Mean group size was 4.14 (maximum group size $=12$ individuals) and there was no apparent change in group size with season. Water level varied annually by up to $3.5 \mathrm{~m}$, and the mean water transparency was 1.02-1.85 m (range 0.35-3.40 $\mathrm{m}$ ), with the high values recorded during the high water period of 2005 (Fig. 2). Of 210 dens, communal latrines, and campsites recorded, 37\% were categorized as in use throughout the study period, and the species was recorded in the lake throughout the year, regardless of the water level. Those dens recorded as in use $40 \%$ or more of the time during the study period are shown in Fig. 1. Reproduction appears to be seasonal, with the majority of births occurring between July and December, corresponding to the high and receding water levels.

Giant otters started their morning activities between 05.23 and $08.05(n=44)$. The difficulty of navigating among the dead trees of the flooded forest during the night limited the time we could spend close to the otter dens at the end of the day to record the time of the animals' return but we recorded times of 15.45-18.21 ( $\mathrm{n}=18)$.

The predominant soil types of the riverbanks in Balbina reservoir are the ultisols, acid and deep or moderately deep, and oxisol, acid and with a low natural fertility (ELETRONORTE, 2005). The giant otter den openings had an average height of $28.77 \pm$ SD $10.00 \mathrm{~cm}$ (range 16-58 $\mathrm{cm} ; \mathrm{n}=49$ ) and an average width of $56.11 \pm$ SD $19.17 \mathrm{~cm}$ (range 22-105 cm; $\mathrm{n}=49$ ), and were oval, round or elongated in shape.

\section{Discussion}

The concentration of $P$. brasiliensis dens in use in the upper part of the surveyed area (Fig. 1) is probably because the influence of the dam is less there than elsewhere, and the margins of this part of the lake are probably similar to how they were before damming. Most of the observations were carried out in this area of the lake because it is easier both to navigate and observe giant otter dens there than in the lower part of the lake. Nevertheless, at least 10 giant otter groups and their dens and campsites were monitored in other parts of the lake, and these are also resident groups. Although some dens are frequently used ( $40 \%$ or more of the time; Fig. 1$)$ 
there also appears to be a high turnover rate of dens, probably caused by water level variation, habitat availability, and the presence of predators such as jaguars. New giant otter den entrances are usually smaller than those of older dens, as constant use tends to increase their size (Duplaix, 1980; Schweizer, 1992). However, it is difficult to determine by size alone whether a den is in fact new as opposed to in use or not.

The seasonality of giant otter births in Balbina lake, occurring mainly during the periods of high and receding water, corroborates the data presented by Duplaix (1980) and Laidler (1984) for giant otters in habitats with little or no human interference and seems to be an intrinsic characteristic of the species in the Amazon region. During these periods it is easier for giant otters to move in the flooded forest areas and prey on fish, and therefore meet the high nutritional and energetic requirements of giant otter females at the end of gestation and beginning of lactation.

The high number of giant otters observed in Balbina and the use of the lake throughout the year suggest that hydroelectric lakes have potential for the conservation of the species, in contrast to previous beliefs (Rosas et al., 1991). However, the use of reservoirs by giant otters appears to depend on at least two conditions: (1) the presence of the species in the area prior to the formation of the lake, and (2) reduced human presence after the formation of the lake. It is known that giant otters occurred in the Uatumã River before the dam was built (Colares, 1988) and there are few human communities in the area. All the flooded area of the reservoir on the left bank of the Uatumã River is a Biological Reserve (ReBio Uatumã). By Brazilian law human inhabitants are not allowed in biological reserves and therefore ReBio Uatumã appears to have been fundamental for giant otter conservation. Although the period in which giant otters established their new territories on the lake is unknown they appear to have benefited from the c. 3,300 islands that were formed by the creation of the lake. All the dens, communal latrines, campsites and territories previously used by giant otters were submerged during the formation of the lake and those that survived probably moved to the headwaters of the Uatumã River basin. Before the damming, giant otters only had the Uatumã River and its tributaries available for dens and territories. With the flooding and the formation of new islands, the land accessible for giant otters increased greatly, presumably allowing the otter population to expand.

Although the giant otter occurred in the Curuá-Una River and its tributaries before the reservoir formation of the Curuá-Una Hydroelectric Dam (near Santarém City, Pará state, Brazil) the lake has never been used by giant otters (F. Rosas, pers. obs.). It is possible that the absence of giant otters is related to the small size of the CuruáUna lake $\left(86 \mathrm{~km}^{2}\right)$ but probably the main factor that prevents use by the giant otter is the density of humans in the area (c. one community per $8 \mathrm{~km}^{2}$ of the lake). In addition, there are no islands in Curuá-Una lake and giant otters would therefore only have the reservoir edges for their dens and territories.

Turning a water body from a lotic to a lentic system by damming a river causes many disturbances. During the early years of the formation of Balbina lake hydrogen sulfide gas from leaf decomposition of the permanently flooded trees reduced concentrations of dissolved oxygen (Fearnside, 1989). However, the transparency of the water increased, thereby benefiting giant otters because they are generally visual predators (Rosas et al., 1999). In the first years after damming any river in the Amazon region, predatory fish (such as peacock basses Cichla spp. and piranhas Serrasalmus spp.) tend to predominate (Leite \& Bittencourt, 1991), and preliminary data indicate that giant otters are consuming $8.5 \%$ more piranhas in Balbina lake than in other areas of Amazonia (Rosas et al., 1999). All these factors are, however, common to most of the hydroelectric lakes in the region but the specific conditions of Balbina reservoir (previous presence of the species in the area and absence of inhabitants around the lake) seem to have facilitated the expansion of the giant otter's population following damming.

All identified giant otter groups in Balbina were observed throughout the study period and are therefore resident. Although solitary otters were seen, some of them belonged to family groups that sometimes split up during the day but reunited in the evening to sleep in the same den. This behaviour makes it difficult to identify temporarily solitary animals from actual transient individuals. However, the high number of giant otters in Balbina indicates the capacity of the species to adapt to the new conditions imposed by river damming. Nevertheless, in order to determine the real potential of hydroelectric power stations for the conservation of giant otters in Amazonia, medium- or long-term studies of this species in other reservoirs are required.

Our study of the giant otter in Balbina reservoir continues and is now focusing on behaviour, group dynamics, reproduction, diet and habitat use. Similar studies have been conducted in other Amazonian areas without hydroelectric influence to make comparisons that will provide information for the conservation of this Threatened species.

\section{Acknowledgements}

We thank Fundação de Amparo à Pesquisa no Estado do Amazonas, Fundação O Boticário de Proteção à 
Natureza, Miami Metro Zoo, Reserva Biológica Uatumã (ReBio Uatumã/IBAMA), Manaus Energia S.A., Philadelphia Zoo, and CNPq Processo N³02712/2003-8, for financial support. We thank Kesä K. Lehti who kindly revised the English version of the manuscript. We also thank three anonymous referees who provided critical and insightful comments on the manuscript.

\section{References}

Best, R.C. (1984) The aquatic mammals and reptiles of the Amazon. In The Amazon. Limnology and Landscape Ecology of a Mighty Tropical River and its Basin (ed. H. Sioli), pp. 371-412. Dr W. Junk Publishers, Dordrecht, The Netherlands.

Carter, S.K. \& Rosas, F.C.W. (1997) Biology and conservation of the giant otter Pteronura brasiliensis. Mammal Review, 27, 1-26.

Colares, E.P. (1988) Lontras da bacia do Rio Uatumã, AM. In III Reunión de Trabajo de Especialistas en Mamíferos Acuáticos de América del Sur (eds R. Praderi, H. Castello \& R. Vaz-Ferreira), p. 29. Museo Nacional de Historia Natural de Montevideo, Montevideo, Uruguay.

Duplaix, N. (1980) Observations on the ecology and behavior of the giant river otter Pteronura brasiliensis in Suriname. Revue Ecologique (Terre et Vie), 34, 495-620.

ELETRONORTE (2005) Características técnicas - UHE Balbina. Http://www.eletronorte.gov.br/meiobal2.htm [accessed 22 August 2006]

Fearnside, P.M. (1989) Brazil's Balbina Dam: environment versus the legacy of the pharaohs in Amazonia. Environmental Management, 13, 401-423.

FUNCATE/INPE/ANEEL (2000) Mapeamento por satélite das áreas inundadas por reservatórios de hidrelétricas brasileiras. Unpublished Report. Convênio FUNCATE/INPE/ANEEL, San Paolo, Brazil [http://www.inpe.br, accessed 20 April 2006].

Groenendijk, J., Hayek, F., Duplaix, N., Reuther, C., Van Damme, P., Schenck, C., Staib, E., Wallace, R., Waldemarin, H., Notin, R., Marmontel, M., Rosas, F., de Mattos, G.E., Evangelista, E., Utreras, V., Lasso, G., Jacques, H., Matos, K., Roopsind, I. \& Botello, J.C. (2005) Surveying and monitoring distribution and population trends of the giant otter (Pteronura brasiliensis) - guidelines for a standardization of survey methods as recommended by the Giant Otter Section of the IUCN/SSC Otter Specialist Group. Habitat, 16, 1-100.

IUCN (2006) 2006 IUCN Red List of Threatened Species. IUCN, Gland, Switzerland [http:/ /www.redlist.org, accessed 14 August 2006].
Laidler, P.E. (1984) The behavioral ecology of the giant otter in Guyana. PhD thesis, University of Cambridge, Cambridge, UK.

Leite, R.A.N. \& Bittencourt, M.M. (1991) Impacto das hidrelétricas sobre a ictiofauna da Amazônia: o exemplo de Tucuruí. In Bases científicas para estratégias de preservação e desenvolvimento da Amazônia: fatos e perspectivas, Vol. I (eds A.L. Val, R. Figliuolo \& E. Feldberg), pp. 85-100. Imprensa Universitária, Manaus, Brazil.

Rosas, F.C.W. (2004) Ariranha, Pteronura brasiliensis (Carnivora: Mustelidae). In História natural, ecologia e conservação de algumas espécies de plantas e animais da Amazônia (ed. R. Cintra), pp. 265-269. EDUA/INPA, Manaus, Brazil.

Rosas, F.C.W., Colares, E.P., Colares, I.G. \& da Silva, V.M.F. (1991) Mamíferos aquáticos da Amazônia Brasileira. In Bases científicas para estratégias de preservação e desenvolvimento da Amazônia: fatos e perspectivas, Vol. I (eds A.L. Val, R. Figliuolo \& E. Feldberg), pp. 405-411. Imprensa Universitária, Manaus, Brazil.

Rosas, F.C.W., Zuanon, J.A.S. \& Carter, S.K. (1999) Feeding ecology of the giant otter, Pteronura brasiliensis. Biotropica, 31, 502-506.

Schenck, C. (1999) Lobo de Rio Pteronura brasiliensis - Presencia, uso del hábitat y protección en el Peru. PhD thesis, LudwigMaximilians-Universität, Munich, Germany.

Schweizer, J. (1992) Ariranhas no Pantanal: Ecologia e comportamento da Pteronura brasiliensis. Edibran-Editora Brasil Natureza Ltda., Curitiba, Brazil.

Sioli, H. (ed.) (1984) The Amazon. Limnology and Landscape Ecology of a Mighty Tropical River and its Basin. Dr W. Junk Publishers, Dordrecht, The Netherlands.

\section{Biographical sketches}

Fernando C.W. Rosas has been working with the biology, ecology, and conservation of Brazilian aquatic mammals, especially of the Amazon, for over 25 years. He is a senior researcher of the National Institute of Amazonian Research (INPA) and is currently engaged in the ecology and conservation of Amazonian manatees, and giant and neotropical otters. He is a member of the IUCN Species Survival Commission Otter and Sirenia Specialist Groups. Gália Ely de Mattos has been working in the Brazilian Amazon for 8 years. She is currently working on the giant otter research project at INPA. She is also a member of the Otter Specialist Group. Márcia Munick Mendes Cabral's interests include wildlife conservation and environmental activism. She has been involved in the giant otter project at INPA since 2005 . 